\title{
ANALISIS POTENSI INTERAKSI OBAT PADA RESEP SPESIALIS PENYAKIT KULIT DI SALAH SATU KLINIK DI YOGYAKARTA
}

\author{
Anis Febri Nilansari \\ (Program Studi Farmasi, Fakultas Sains dan Teknologi, Universitas PGRI Yogyakarta)
}

\begin{abstract}
Skin diseases often occur in tropical countries, including Indonesia. Data from the Yogyakarta City Health Office showed that skin diseases were included in the top 10 diseases at the Yogyakarta City Health Center in 2020. Various types of drugs for the treatment of skin diseases, ranging from tablets, ointments, creams, pulvis and shampoos. One of the accuracy in drug selection is to avoid drug interactions. Drug-drug interaction (DDI) occurs when two or more drugs can interact in a way that affects the effectiveness of the drug. The purpose of this study is to determine the number and categories of drug interactions. This research was carried out retrospectively by taking medical data on skin diseases at one of the skin and genital clinics in the city of Yogyakarta. The data collection period is for 2 months, namely September and October 2020. The data taken are in the form of demographic data and drug use. The results showed that there were 33 cases of minor interactions. There were 21 cases of loratadine and steroids, 2 cases of ketoconazole and steroid interactions, and 10 cases of cefadroxil and acyclovir interactions. The conclusion is that offering drug combinations that allow drug interactions to occur can avoid drug combinations taken simultaneously and use only in special circumstances. It is recommended that pharmacists provide information on the rules for taking medication to maximize the effectiveness of the drug in curing the patient's illness.
\end{abstract}

Keywords: drug interaction; dermatology; DDI

\begin{abstract}
Abstrak
Penyakit kulit sering terjadi pada negara beriklim tropis termasuk Indonesia. Data Dinas Kesehatan Kota Yogyakarta menunjukkan bahwa penyakit kulit masuk dalam 10 besar penyakit di Puskesmas Kota Yogyakarta pada tahun 2020. Berbagai macam jenis obat untuk pengobatan penyakit kulit, mulai dari sediaan tablet, salep, cream, pulvis dan shampo. Salah satu ketepatan dalam pemilihan obat yaitu menghindari adanya interaksi obat. Interaksi obat dengan obat atau Drug-Drug Interaction (DDI) terjadi ketika dua atau lebih obat dapat berinteraksi dengan cara mempegaruhi efektivitas obat. Penelitian ini bertujuan untuk mengetahui jumlah dan kategori interaksi obat sehingga dapat mejadi evaluasi apoteker dan dokter dalam pemilihan obat yang aman dan efektif bagi pasien. Penelitin ini dilakukan secara retrospektif dengan mengambil data rekam medis pasien penyakit kulit di salah satu klinik kulit dan kelamin di Kota Yogyakarta. Periode pengambilan data selama 2 bulan yaitu September dan Oktober 2020. Data yang diambil berupa data demografi dan penggunaan obat, yang dianalisis menggunakan analisa univariat. Hasil penelitian menunjukkan terdapat 33 kasus interaksi minor. Interaksi terjadi antara loratadine dengan golongan steroids sebanyak 21 kasus, interaksi ketoconazole dengan golongan steroid sebanyak 2 kasus, dan interaksi cefadroxil dan acyclovir sebanyak 10 kasus. Kesimpulannya ialah pemberian kombinasi obat yang memungkinkan terjadinya interaksi obat dapat dicegah dengan menghindari kombinasi obat yang diminum secara bersamaan dan menggunakannya hanya dalam keadaan khusus. Disarankan apoteker memberikan informasi aturan minum obat untuk memaksimalkan efektivitas obat dalam menyembuhkan penyakit pasien.
\end{abstract}

Kata kunci: interaksi obat; dermatologi; DDI 


\section{PENDAHULUAN}

Kulit merupakan bagian dari sistem integumen yang merupakan bagian terbesar organ tubuh manusia ${ }^{1,2}$. Penyakit kulit sering terjadi dan menyebabkan beban penyakit yang besar secara global. Secara kolektif, kulit adalah penyebab utama beban kesehatan ke-18 di seluruh dunia dan merupakan penyebab utama ke-4 dari beban kesehatan nonfatal pada tahun 2010 secara global ${ }^{3}$.

Penyakit kulit sering terjadi pada negara beriklim tropis, termasuk Indonesia. Prevalensi penyakit kulit di negara berkembang antara $20-80 \%$. Kejadian penyakit kulit di Indonesia masih tergolong tinggi dan menjadi permasalahan kesehatan yang cukup berarti ${ }^{4}$. Data Profil Dinas Kesehatan Kota Yogyakarta Tahun 2021 menunjukkan bahwa penyakit kulit masuk dalam 10 besar penyakit pasien rawat jalan di Puskesmas Kota Yogyakarta pada tahun $2020^{5}$.

Penyakit kulit di Indonesia pada umumnya lebih banyak disebabkan karena infeksi bakteri, jamur dan virus. Penyakit kulit adalah penyakit yang sering diderita oleh masyarakat akibat lingkungan dan air tidak bersih. Umumnya penyakit kulit bukan merupakan penyakit yang mematikan, sehingga banyak diabaikan oleh sebagian besar orang. Namun pengobatan dan penangan yang tidak tepat dapat menurunkan kualitas hidup penderita ${ }^{6}$.

Berbagai macam jenis obat untuk pengobatan penyakit kulit, mulai dari sediaan tablet, salep, cream, pulvis dan shampo. Salah satu ketepatan dalam pemilihan obat yaitu menghindari adanya interaksi obat. Obat yang diberikan dengan obat lain, jamu, makanan, dan minuman dapat menyebabkan interaksi obat. Interaksi obat memberikan keuntungan dengan meningkatkan efektivitas obat, tetapi juga memberikan kerugian seperti mengurangi efektivitas obat, adanya efek samping, dan bahkan toksisitas ${ }^{7}$.

Interaksi obat berdasarkan mekanisme dibagi menjadi farmasetika, farmakokinetik, dan farmakodinamik ${ }^{8}$. Berdasarkan kejadiannya, dibagi menjadi aktual dan interaksi obat potensial, sementara berdasarkan tingkat keparahan dibagi menjadi minor, moderate, mayor, dan kontraindikasi. Kategori minor, interaksi obat secara klinis tidak menimbulkan efek yang signifikan. Kategori mayor membutuhkan pemantauan selama terapi, sedangkan kategori kontraindikasi menimbulkan efek yang signifikan sehingga direkomendasikan untuk dimodifikasi dengan terapi lain ${ }^{7}$.

Interaksi obat dengan obat atau Drug-Drug Interaction (DDI) terjadi ketika dua atau lebih obat dapat berinteraksi dengan cara mempegaruhi efektivitas obat. DDI dianggap sebagai masalah terkait pengobatan yang dapat dicegah. Angka kejadian DDI dalam pengobatan sebanding dengan jumlah obat yang diresepkan oleh dokter. Sebuah studi oleh Nolan dan O'Malley menunjukkan bahwa pasien yang menggunakan sepuluh atau lebih obat memiliki lebih dari $90 \%$ kemungkinan memiliki satu atau lebih DDI yang signifikan secara klinis. 
Beberapa penelitian di lebih dari 370.000 pasien menunjukkan bahwa 2,2\% -70,3\% dapat mengalami DDI potensial ${ }^{9,10}$.

Sedangkan berdasarkan penelitian Diksis tahun 2019, dari 673 resep pasien yang dianalisis, terdapat 521 resep yang mengalami interaksi obat potensial. Tingkat prevalensi interaksi obat potensial secara keseluruhan sebesar $74,41 \%$. Faktor yang sangat berpengaruh pada kasus interaksi obat terjadi pada pasien usia lanjut, lama pengobatan $\geqslant 7$ hari dan adanya polifarmasi ${ }^{11}$.

Sehingga berdasarkan latar belakang tersebut dilakukan potensi interaksi obat pada resep spesialis kulit di salah satu Klinik Kulit di Yogyakarta. Penelitian ini bertujuan untuk mengetahui jumlah dan kategori interaksi obat sehingga menjadi evaluasi apoteker dan dokter dalam pemilihan obat yang aman dan efektif bagi pasien

\section{METODE PENELITIAN}

Penelitin ini dilakukan secara retrospektif dengan mengambil data rekam medis pasien penyakit kulit di salah satu Klinik Kulit di Yogyakarta. Periode pengambilan data selama 2 bulan yaitu September dan Oktober 2020.

Data berupa Lembar Pengambilan Data (LPD) pasien penyakit kulit dan kelamin yang berisi data demografi pasien (nomor rekam medik, jenis kelamin, umur, dan waktu periksa) dan penggunaan obat (nama obat, frekuensi dan dosis, bentuk sediaan, tanggal pemberian, lama pemberian, dan diagnosis penyakit oleh dokter).

Penelitian ini merupakan penelitian kuantitatif yang bertujuan untuk mengetahui jumlah dan jenis interaksi obat yang terjadi pada salah satu Klinik Kulit di Yogyakarta. Tempat penelitian berada di bagian administrasi (rekam medik) dan apotek di salah satu Klinik Kulit di Yogyakarta.

Kriteria inklusi yaitu data pasien penyakit kulit dan kelamin di salah satu Klinik Kulit di Yogyakarta dengan data demografi dan data penggunaan obat yang lengkap. Kriteria inklusi dipilih selain pasien dengan diagnosa perawatan kecantikan kulit dan wajah.Kriteria eksklusi yaitu pasien yang tidak memiliki data deografi dan data penggunaan obat yang tidak lengkap. Pasien dengan diagnosa perawatan kecantikan kulit dan wajah dimasukkan dalam kriteria eksklusi.

Teknik analisis data yang digunakan dalam penelitian ini adalah analisa univariat. Pada umumnya dalam analisis ini hanya menghasilkan distribusi frekuensi dan persentase dari tiap variable. Analisis data dilakukan dengan mengkaji setiap resep yang masuk dalam kriteria inklusi dengan melihat angka kejadian interaksi obat. Media yang digunakan untuk melihat kejadian interaksi obat digunakan aplikasi Drug Interaction Checker yang dapat diakses melalui https://www.drugs.com/drug interactions.html. Pada aplikasi tersebut, peneliti memasukkan masing-masing obat yang diresepkan oleh dokter, kemudian akan 
muncul kejadian interaksi obat yang dapat di klasifikasikan dalam kategori interaksi minor, mayor dan moderate. Data kategori interaksi yang diperoleh kemudian dijadikan data hasil penelitian ${ }^{12}$.

\section{HASIL PENELITIAN}

Berdasarkan tabel 1 dapat dilihat data demografi pasien penyakit kulit disalah satu klinik di Yogyakarta bahwa 55,4\% pasien penyakit kulit didominasi dengann jenis kelamin perempuan. Berdasarkan usia, paien dengan terbanyak yaitu pada rentang usia 0 bulan sampai 10 tahun, kemudian terbanyak kedua yaitu pasien denan rentang usia 21 sampai 30 tahun.

\begin{tabular}{|c|c|c|}
\hline Karakteristik Demografi & Jumlah Pasien & $\begin{array}{c}\text { Persentase } \\
(\%)\end{array}$ \\
\hline \multicolumn{3}{|l|}{ Jenis Kelamin } \\
\hline Laki laki & 255 & 44,6 \\
\hline Perempuan & 317 & 55,4 \\
\hline \multicolumn{3}{|l|}{ Usia } \\
\hline 0 bulan- 10 tahun & 133 & 23 \\
\hline $11-20$ tahun & 70 & 12 \\
\hline $21-30$ tahun & 96 & 17 \\
\hline $31-40$ tahun & 79 & 14 \\
\hline $41-50$ tahun & 64 & 11 \\
\hline $51-60$ tahun & 51 & 9 \\
\hline$>60$ tahun & 79 & 14 \\
\hline
\end{tabular}

Berdasarkan tabel 2 dapat dilihat variasi jumlah obat pasien penyakit kulit disalah satu klinik di Yogyakarta bahwa jumlah obat yang diberikan pling banyak yaitu rentang 1-3 item obat, dilanjutkan 4-6 item obat dan paling sedikit lebih dri 6 item obat.

Tabel 2. Variasi Jumlah Obat Pasien Penyakit Kulit di Salah Satu Klinik di Yogyakarta Bulan September dan Oktober 2020

\begin{tabular}{ccc}
\hline $\begin{array}{c}\text { Variasi Jumlah } \\
\text { Obat }\end{array}$ & $\begin{array}{c}\text { Jumlah } \\
\text { Pasien }\end{array}$ & $\begin{array}{c}\text { Persentase } \\
(\%)\end{array}$ \\
\hline $1-3$ & 362 & 63 \\
\hline $4-6$ & 158 & 28 \\
\hline$>6$ & 52 & 9 \\
\hline
\end{tabular}

Berdasarkan tabel 3 dapat dilihat data penggunaan obat pasien penyakit kulit disalah satu klinik di Yogyakarta bahwa terdapat 8 macam golongan obat oral yang digunakan, sedangkan untuk obat topikal terdapat 7 macam golongan obat yang digunakan. 


\section{Tabel 3. Penggunaan Obat Pasien Penyakit Kulit di Salah Satu Klinik di} Yogyakarta Bulan September dan Oktober 2020

\begin{tabular}{|c|c|c|}
\hline No & Obat Topikal & Obat Sistemik \\
\hline 1. & $\begin{array}{l}\text { Antijamur } \\
\text { Ketoconazole } \\
\text { Mikonazole }\end{array}$ & $\begin{array}{l}\text { Antijamur } \\
\text { Itraconazole, } \\
\text { Ketokonazol, } \\
\text { Griseovulvin }\end{array}$ \\
\hline 2. & $\begin{array}{l}\text { Antibiotik } \\
\text { Asam Fusidat } \\
\text { Mupirocin, } \\
\text { Klindamisin }\end{array}$ & $\begin{array}{l}\text { Antibiotik } \\
\text { Cefixim, } \\
\text { Cefadroxil, } \\
\text { Dosisklin, } \\
\text { Ciproflokasasin } \\
\text { Azithromycin }\end{array}$ \\
\hline 3. & $\begin{array}{l}\text { Steroids } \\
\text { Clobetasol } \\
\text { Hidrokortison } \\
\text { Desonide } \\
\text { Betametason, } \\
\text { Mometason, } \\
\text { Desoximetason }\end{array}$ & $\begin{array}{l}\text { Steroids } \\
\text { Metilprednisolon, } \\
\text { Triamcinolon }\end{array}$ \\
\hline 4. & $\frac{\text { Antiparasit }}{\text { Premetrin }}$ & $\frac{\text { Anti virus }}{\text { Acyclovir }}$ \\
\hline 5. & $\begin{array}{l}\text { Keratolitik } \\
\text { Asam Mefenamat } \\
\text { Carmed }\end{array}$ & $\begin{array}{l}\text { Antihistamin } \\
\text { Loratadine } \\
\text { Cetirize }\end{array}$ \\
\hline 6. & $\frac{\text { Retinoid }}{\text { Tretinoin }}$ & $\begin{array}{l}\text { Antagonis } \mathrm{H} 2 \\
\text { Cimetidine } \\
\text { Ranitidine }\end{array}$ \\
\hline 7. & $\frac{\text { Emolien }}{\text { Vaseline }}$ & $\frac{\text { Antihelmintik }}{\text { Albendazole }}$ \\
\hline 8. & & $\begin{array}{l}\text { Analgetik } \\
\text { Asam Mefenamat } \\
\text { Paracetamol }\end{array}$ \\
\hline
\end{tabular}

\section{PEMBAHASAN}

Interaksi obat-obat (DDI) digambarkan sebagai kemampuan satu obat untuk meningkatkan, mengurangi dan/atau memodifikasi aksi atau efek obat lain ketika diberikan secara berurutan atau bersamaan ${ }^{13}$. DDI adalah jenis efek samping obat yang sangat penting karena dapat mengubah efektivitas dan keamanan obat ${ }^{14}$. Meskipun tidak selalu dapat dihindari, DDI sering dapat diprediksi ${ }^{15}$.

Pada penelitian ini dilakukan untuk jumlah dan kategori interaksi obat yang resep penyakit kulit di salah satu klinik kulit di Yogyakarta. Penelitian dilakukan dengan mengidentifikasi interaksi obat yang terjadi dengan menggunakan aplikasi Drug Interaction 
Checker. Pengambilan data pada penelitain ini meliputi data demografi dan dala penggunaan obat. Berdasarkan hasil pengambilan data resep selama 2 periode yaitu September dan Oktober 2021, diperoleh sebanyak 592 resep.

Hasil penelitian berdasarkan demografi pasien diperoleh sebanyak 55,4\% pasien penyakit kulit di salah satu Klinik Kulit di Yogyakarta didominasi dengann jenis kelamin perempuan. Berdasarkan usia, paien dengan terbanyak yaitu pada fase usia bayi sampai anak-anak, kemudian disusul fase dewasa.

Hasil penelitian ini serupa dengan penelitian yang dilakukan oleh Flinka pada tahun 2006 bahwa penyakit kuit di dominasi oleh pasien dengan jenis kelamin perempuan, dengan perbandingan laki-laki dan perempuan yaitu 1: 1,2. Rentang usia terbanyak yaitu fase anakanak, dilanjutkan fase infartil dan yang terakhir fase dewasa ${ }^{16}$.

Berdasarkan jenis sediaan yang diresepkan, terdapat 2 sediaan yaitu obat oral dan topkal. Obat oral yang diresepkan ialah golongan antibiotik, antijamur, antivirus, steroid, antihistamin, multivitamin, antagonis $\mathrm{H} 2$, analgetik dan antihelmintik. Sedangkan untuk obat topikal digunakan golongan antijamur, antibiotik, steroids, antiparasit, keratolitik, retinoid, dan emolien.

Resep tersebut dilakukan analisis kejadian terjadinya interaksi obat dengan menggunakan aplikasi drug interaction checker. Hasil penelitian diperoleh interaksi minor sebanyak 33 kasus. Interaksi terjadi antara loratadine dengan golongan steroids sebanyak 21 kasus, interaksi ketoconazole dengan golongan steroid sebanyak 2 kasus, dan interaksi cefadroxil dan acyclovir sebanyak 10 kasus.

Interaksi yang terjadi antara pemberian loratadine dengan methyl prednisolon ialah methylprednisolone akan menurunkan level atau efek loratadine dengan memengaruhi metabolisme enzim CYP3A4 hati / usus.

Sedangkan untuk interaksi minor anatara pemberian ketoconazole dan methyl prednisolon, dimana ketoconazole akan meningkatkan kadar atau efek prednisolon dengan mempengaruhi metabolisme enzim CYP3A4 di hati/usus. Pemberian cefadroxil dengan acyclovir secara bersaam juga akan menyebabkan interaksi minor dengan cara cefadroxil akan meningkatkan efek asiklovir dengan kompetisi obat asam (anionik) untuk pembersihan di tubulus ginjal.

Hasil klinis DDI dapat bermanifestasi sebagai antagonisme, sinergisme, atau idiosinkrasi. Selain itu, DDI dapat dibagi menjadi interaksi farmakodinamik (PD) dan farmakokinetik (PK). DDI farmakodinamik terkait dengan aktivitas farmakologis dari obat yang berinteraksi, melalui efek langsung pada fungsi reseptor, gangguan dengan proses kontrol biologis atau fisiologis. DDI farmakokinetik terkait dengan efek satu obat pada penyerapan, distribusi, metabolisme atau ekskresi obat lain, dan dapat memodifikasi tingkat konsentrasi obat, yang menyebabkan ketidakefektifan atau toksisitas, dan lebih umum 
daripada DDI farmakodinamik. Interaksi yang terjadi pada penelitian ini ialah interaksi farmakokinetik. DDI aktual diidentifikasi dari hasil yang merugikan pasien sedangkan DDI potensial adalah yang diidentifikasi melalui analisis profil farmakokinetik dan farmakodinamik dari setiap obat yang digunakan ${ }^{17}$.

Olehkarena DDI potensial tidak mengakibatkan hasil yang merugikan, sehingga angka kejadian DDI aktual dalam literatur secara konsisten lebih rendah dibandingkan dengan DDI potensial, sehingga setiap pasien harus dievaluasi secara individual, dengan mempertimbangkan rasio risiko-manfaat ${ }^{13}$.

Menurut penelitian Kappa tahun 2013, prevalensi DDI terjadi pada hampir 40\% pada pasien yang menggunakan lima macam obat dan lebih dari $80 \%$ pada pasien yang menggunakan tujuh atau lebih macam obat. Hasil analisis pada penelitian ini tidak ditemukan banyak interaksi obat karena pemberian obat oral lebih dari dua tablet jarang diberikan kepada pasien ${ }^{18}$.

Selain itu, interaksi obat topikal juga dapat ditemukan pada beberapa obat. Berbagai obat yang dioleskan pada kulit atau selaput lendir menghasilkan efek terapeutik yang terlokalisasi di tempat aplikasi. Meskipun beberapa bagian dari obat topikal diserap, obat tersebut biasanya tidak memiliki banyak aksi sistemik kecuali telah digunakan untuk jangka waktu yang lama. Obat yang dioleskan mungkin memiliki interaksi dengan obat topikal lain serta obat sistemik. Konsep yang mendasari penggunaan berbagai obat dan kombinasi dalam bentuk topikal adalah untuk menghindari efek samping sistemik dari sediaan sistemik .Interaksi obat-obat topikal dapat bersifat agonis atau antagonis. Contoh interaksi obat topikal agonis adalah penggunaan deksametason dengan tretinoin, di mana tretinoin membantu penyerapan dari hidrokuinon ${ }^{19}$.

Pemberian kombinasi obat yang memungkinkan terjadinya interaksi obat dapat dicegah dengan menghindari kombinasi obat yang diminum secara bersamaan dan menggunakannya hanya dalam keadaan khusus. Peran apoteker dalam memberikan informasi aturan minum obat dibutuhkan untuk memaksimalkan efektivitas obat dan mencegah timbulnya efek yang tidak diinginkan. Apoteker memiliki peran utama dalam mencegah DDI terutama dengan mengevaluasi resep dokter dengan adanya kemungkinan terjadinya DDI. Oleh karena itu, interaksi profesional terintegrasi antar tenaga kesehatan dibutuhkan untuk mengoptimalkan keamanan obat. Diperlukan kewaspadaan tenaga kesehatan seperti dokter, apoteker, dan perawat dalam mendeteksi, mendiagnosis, dan melaporkan DDI, terutama pada individu berisiko yang memiliki morbiditas penting dilakukan untuk pemantauan keamanan pengguaan obat. 


\section{SIMPULAN DAN SARAN}

Kesimpulan penelitian ini menunjukkan bahwa pemberian kombinasi obat yang memungkinkan terjadinya interaksi obat dapat dicegah dengan menghindari kombinasi obat yang diminum secara bersamaan dan menggunakannya hanya dalam keadaan khusus. Disarankan apoteker memberikan informasi aturan minum obat untuk memaksimalkan efektivitas obat dalam menyembuhkan penyakit pasien. Saran dari penelitian yaitu diperlukan peran apoteker dalam memberikan informasi aturan minum obat untuk memaksimalkan efektivitas obat dan mencegah timbulnya gagal terapi dan medication error.

\section{DAFTAR PUSTAKA}

1. Pathak AK, Kumar S, Kumar M, Mohan L, Dikshit H. Study of drug utilization pattern for skin diseases in dermatology opd of an indian tertiary care hospital - A prescription survey. Journal of Clinical and Diagnostic Research. 2016;10(2):FC01-5.

2. Lakshmi GNSS, Priyanka C, Vineela M. Drug utilisation pattern in dermatology outpatient department at a tertiary care hospital. International Journal of Basic \& Clinical Pharmacology. 2018;7(11):2101.

3. Hay RJ, Johns NE, Williams HC, Bolliger IW, Dellavalle RP, Margolis DJ, et al. The global burden of skin disease in 2010: An analysis of the prevalence and impact of skin conditions. Journal of Investigative Dermatology. 2014;134(6):1527-34.

4. Oktaviani F, Mukaddas A, Faustine I. Drug Use Profile of Patients With Skin Disease At Dermatology and Venereology Polyclinic in Anutapura General Hospital Palu. GALENIKA Journal of Pharmacy. 2016;2(March):38-42.

5. Dinas Kesehatan Kota Yogyakarta. Profil Kesehatan Kota Yogyakarta Tahun 2021. Yogyakarta; 2021.

6. Tijaniyah, Sarosa M, Dachlan HS. Pemilihan Obat Penyakit Kulit Menggunakan Teknik Multi Attribute Decision Making . elektronik Jurnal Arus Elektro Indonesia (eJAEI). 2016;13-22.

7. Baxter K. Stockley's Drug Interactions. 9th ed and Stockley's Drug Interactions 2010 Pocket Companion. Journal of the Medical Library Association. 2011;

8. Rahayu S. INTERAKSI ANTAR OBAT PADA PERESEPAN PASIEN RAWAT INAP PEDIATRIK RUMAH SAKIT X DENGAN MENGGUNAKAN APLIKASI MEDSCAPE (Drug Interaction Between The Prescribing Pediatric Inpatients At Hospital X Using Medscape Applications) [Internet]. Vol. 1. 2018. Available from: www.medscape.com

9. Gleason LJ, Luque AE, Shah K. Polypharmacy in the HIV-infected older adult population. Clinical Interventions in Aging. 2013;8:749-63. 
10. Khandeparkar A, Rataboli P. A study of harmful drug-drug interactions due to polypharmacy in hospitalized patients in Goa Medical College. Perspectives in Clinical Research. 2017;8(4):180-6.

11. Diksis N, Melaku T, Assefa D, Tesfaye A. Potential drug-drug interactions and associated factors among hospitalized cardiac patients at Jimma University Medical Center, Southwest Ethiopia. SAGE Open Medicine. 2019;7:205031211985735.

12. Khoirunnisa I, Pradana ES, Lestari K, Studi P, Apoteker P, Padjadjaran U. ANALISIS POTENSI INTERAKSI OBAT PADA RESEP SPESIALIS PENYAKIT KULIT DAN KELAMIN DI SALAH SATU KLINIK DI KOTA BANDUNG. Farmaka. 2021;19:1-6.

13. De Oliveira LM, Diel JDAC, Nunes A, Da Silva Dal Pizzol T. Prevalence of drug interactions in hospitalised elderly patients: A systematic review. European Journal of Hospital Pharmacy. 2021;28(1):4-9.

14. Montané E, Arellano AL, Sanz Y, Roca J, Farré M. Drug-related deaths in hospital inpatients: A retrospective cohort study. British Journal of Clinical Pharmacology. 2018;84(3):542-52.

15. de Oliveira LM, Diel JDAC, Nunes A, da Silva Dal Pizzol T. Prevalence of drug interactions in hospitalised elderly patients: A systematic review. Vol. 28, European Journal of Hospital Pharmacy. BMJ Publishing Group; 2021. p. 4-9.

16. Keles FF, Pandaleke HEJ, Mawu FO. Profil dermatitis atopik pada anak di Poliklinik Kulit dan Kelamin RSUP Prof. Dr. R. D. Kandou Manado periode Januari 2013 Desember 2015. e-CliniC. 2016;4(2).

17. Palleria C, Di Paolo A, Giofrè C, Caglioti C, Leuzzi G, Siniscalchi A, et al. Pharmacokinetic drug-drug interaction and their implication in clinical management. Journal of Research in Medical Sciences. 2013;18(7):600-9.

18. Kapp PA, Klop AC, Jenkins LS. Drug interactions in primary health care in the George subdistrict, South Africa: A cross-sectional study. South African Family Practice. 2013;55(1):78-84.

19. Arijit Coondoo CC. Drug Interactions in Dermatology: What the Dermatologist Should Know. Indian Journal of Dermatology. 2013. 